\title{
Alterations of Some Heavy Metals and Trace Elements Levels in Breast Cancer
}

Parween Abdul Samad Ismail ${ }^{1 *}$, Araz Muhammad Yousif ${ }^{2}$ and Edrees Muhammad Tahir Harki ${ }^{3}$

${ }^{1}$ Clinical Biochemistry Division, Department of Chemistry, College of Education, Salahadine University, Iraq

${ }^{2}$ Clinical and Analytical Biochemistry Division, Department of Biochemisty, Hawler Medical University, Iraq

${ }^{3}$ Department of Physics, College of Education, Salahadine University, Iraq

\begin{abstract}
Background: Breast cancer is the most familiar malignancy in females. It is one of the most common causes of cancer mortality in females.
\end{abstract}

Objectives: The aim of our research is to estimate alteration of trace metals in breast cancer. The heavy and essential metals levels were determined in the serum of breast cancer patients, inorder to detect their importance in the treatment and prognosis of the cancer.

Methods: It was a prospective, case control study. A total of 80 female participants were divided into healthy controls $(n=40)$ and breast cancer $(n=40)$. The serums of As, Fe, Cd, Ni, Cr, Mg, Mn, Co and Se were analysed by atomic absorption spectrophotometery.

Results: The serum means of $\mathrm{Mg}, \mathrm{Cd}, \mathrm{Ni}, \mathrm{Cr}, \mathrm{Fe}, \mathrm{Co}$ and $\mathrm{Se}$ levels were significantly increased in breast cancer patients, when compared with the controls $(p<0.001, p<0.0017, p<0.001, p<0.05, p<0.008, p<0.05$, and $p<0.001$, respectively). The mean serum As and Mn levels were significantly lowerd in breast cancer patients compared with the controls $(P<0.001$ and $P<0.0019)$.

Conclusion: Alteration of the elemental amount in cancerous breast tissues and the disturbance of oxidant/ antioxidant balance high light the part of trace metals in cancer expansion. The alterations of these biochemical metals in the serum of breast cancer patients aid in appropriate treatment as well as indicators of prognosis as the disease progress.

Keywords: Trace metals; Breast cáncer; Prognosis

\section{Introduction}

The cancer of breast is highly heterogeneous illness globally. The absolute risk of breast cancer raises with age and is sky-high in postmenopausal females. Breast cancer reports $16 \%$ of all cancer deaths among females globally, according to the reaserch by the World Health Organization. It is the most frequent solid tumour diagnosed in females [1]. The environmental effects during embryogenesis, childhood, and adolescence may affect breast cancer appearance in adulthood by stumilating or lowering carcinogenic processes [2]. The embryo develops quickly and toxic agents that transport through placental barrier can have specific enflunces on organ enlargement depending on the time at which the manifestation occurs. Although breast tissue starts to evolve by the fourth week of development, the breast is unfamiliar among body parts in that it stays relatively unchanged until puberty or later [3]. Trace elements are essential materials of biological structures, but at the similar time these can be toxic at levels beyond required for their biological functions. The toxicity can be increased to other nonessential elements of similar atomic predictables that can imitate there activity of a trace [4]. Trace elements are present in small levels, but they act a vital part in plentiful biochemical enzymatic reactions and have been evaluated as a potential key constituent in various human diseases involving cancer. Some trace elements do play a preventive role against malignant growth by involving in protection against oxidative stress which can generate free radicals in the cells that contribute to cancer development [5]. Natural trace elements such as: zinc, copper, lead and iron are found in the environment, and human exposure derives from different sources involving air, drinking water and food. It is known that trace elements have important effects as a constituent of various enzymes on a huge number of biological processes. They have some regulatory functions that may affect immune reactions and free radical generation. The cancerous tissue directly indicates changes of trace elements that are evoked by the disease. Blood or blood constituents such as serum are considered to be the best indicators of the present exposure of an individual to many metals due to its easy sampling [6].

\section{Materials and Methods}

All the chemicals and reagents used in the study were of analytical grade and are pure (E. Merck) Doubly distilled demineralized water was operated for all the preparation of solution and washings. The study group consisted of 40 females with diagnosed breast cancer (Cancerous group). All the patients were enrolled in the study before receiving the first course from chemotherapy. The control group consisted of 40 healthy subjects (Non-cancerous group). Venous blood sample (10 ml) was collected of each of the breast cancer patients and healthy group in a metal-free sterile tube, at morning. Heavy metals and trace elements were determined by using Perkin Elmer 2380, atomic absorptions spectrophotometer [7]. Statistical analyses were carried out operating the SPSS 13.0 [8].

*Corresponding author: Parween Abdul Samad Ismail, Clinical Biochemistry Division, Department of Chemistry, College of Education, Salahadine University, Iraq, Tel: +964 66223 0335; E-mail: parween7abdulsamad@yahoo.com

Received January 20, 2017; Accepted January 28, 2017; Published January 31 2017

Citation: Ismail PAS, Yousif AM, Harki EMT (2017) Alterations of Some Heavy Metals and Trace Elements Levels in Breast Cancer. Med Chem (Los Angeles) 7: 758-760. doi: 10.4172/2161-0444.1000426

Copyright: @ 2017 Ismail PAS, et al. This is an open-access article distributed under the terms of the Creative Commons Attribution License, which permits unrestricted use, distribution, and reproduction in any medium, provided the original author and source are credited. 


\section{Results and Disscusion}

Serum levels of As, Fe, Cd, Ni, Cr, Mg, Mn, Co, and Se of healthy females and females with breast cancer were shown in Figure 1. Serum levels of $\mathrm{Mg}, \mathrm{Cd}, \mathrm{Ni}, \mathrm{Cr}, \mathrm{Fe}, \mathrm{Co}$ and Se were significantly higher ( $\mathrm{p}<0.001$, $\mathrm{p}<0.0017, \mathrm{p}<0.001, \mathrm{p}<0.05, \mathrm{p}<0.008, \mathrm{p}<0.05, \mathrm{p}<0.001$, respectively), while serum levels of As and Mn were significantly lower ( $<<0.001$, and $\mathrm{p}<0.0019)$ in with breast cancer patients than in the controls.

In general, metal carcinogenicity and genotoxicity are formed on three main mechanisms: oxidative stress, DNA repair modulation, and disturptions of signal transduction pathways. Interestingly, some trace metals are claimed to be carcinogenic and capable of inducing toxic effect through the formation of ROS and acting as co-factors in the oxidative break of biological macromolecules and DNA. However, their exact role in carcinogenesis is still unclear [9]. Our study demonstrated that concentrations of the serum $\mathrm{Cr}, \mathrm{Ni}$ and $\mathrm{Cd}$ in females with breast cancer elevated when compared to the healthy females as shown in Figure 1.This finding agrees with that reported by some investigators [10]. The serum levels of $\mathrm{Cd}, \mathrm{Cr}$ and $\mathrm{Ni}$ were raised in cancerous breast tissue samples and their suggested act in tumor enlargement could be associated to the disturbance of the oxidative balance, production of oxidative DNA damage and inhibition of DNA repair [11]. The carcinogenic prospective of $\mathrm{Cr}$ (VI) is intiated for humans and animals experimental [12]. However, the mechanisms of molecular of breakdown after exposure to chromium is still not completely understood. Both researchers Hartwig and Schwerdtle 2002 reported that are many verfication that metals plus $\mathrm{Cr}$ can interfere with marked steps of assorted DNA repair systems including oxidative DNA lesions. Coyle et al. [13] explained that Cr was related positively with the rat's breast cancer in Texas.

Ni compounds are familiar carcinogens in both human and animal [14]. The genotoxic influences of $\mathrm{Ni}$ may be through the inhibition of DNA repair systems indirectly [15]. Since nickel has been familiar to reduce the repair of breakdown DNA [16], it may be associated to malignant growth process.

Cadmium is one of well known carcinogens compound to the humans (among exposed workers) based on findings of elevated risk to lung cancer and pancreatic cancer. A remarkable source of $\mathrm{Cd}$ is tobacco, and high levels of Cd may cause many diseases such as: lung and prostate cancer, etc. [17]. The high amount of Cd might have contributed to the pathogenesis of breast cancer. Cadmium has the possiblity to disrupt the function of endocrine by acting like sex hormones. At low levels of metals, they imitates the effects of estradiol and combines with domain hormone-binding of ER-alpha. This binding includes many amino acids, that $\mathrm{Cd}$ may activate the receptor [18]. Early puberty also may have been related with breast cancer [19]. A new study reported by Johnson et al [20] explained that Cd might cause early puberty and breast cancer, by experiment on animal models that exhibit complex interactions, which are needed for determining the carcinogenic possiblity of metals.

In the current study the mean iron levels in the breast cancer group was significantly higher $(\mathrm{p}<0.008)$ than the control group as seen in Figure 1. The agreement of this result with the researchers was done by Konemann et al [21], their results detected high serum iron level in patients with breast cancer; and suggested a correlation between low iron level and breast-cancer. Metal like iron was included in breast tumor igenesis and their suggested that play role in tumor enlargement may be associated to their action as co-factors. Iron can aid carcinogenesis by causing tissue break as it acts as a catalyst in the changing of hydrogen peroxide to free radical ions that attack cellular membranes, damages DNA strands, inactivate enzymes and initiate lipid peroxidation.

\section{Conclusion}

The present study revealed that the mean serum selenium levels in the breast cancer group was significantly higher $(p<0.001)$ than in the healthy group (Figure 1). The integral part of the enzyme glutathione peroxidase, type I iodothyroninedeiodinase, fatty acid binding protein, metalloprotein and selenoprotein $\mathrm{P}$ is Se. Se is considered as an antioxidant micronutrient and in the diseases when the Se levels reduced, it may lead to degenerative diseases such as cancer [22]. In other study revealed a non significant increase in serum Se levels in cancer, which implicating it as a cancer protective agent. This is support of Rotruck et al. research that explaining higher dietary intake of Se may be protective and utilized as anti-carcinogenics [23].

The analysis of results show that the level of $\mathrm{Mg}$ was significantly higher in breast-cancer patientas compared with control (Figure 1). In the cell, $\mathrm{Mg}$ is central, and its deficiency may have an important role in precancerous cell transformation. In addition, $\mathrm{Mg}$-dependent is an immune competence [24]. The high level of $\mathrm{Mg}$ in patients of breast cancer is due to protective effects against cancer.

Figure 1 shows that the level of Mn was significantly $(\mathrm{p}<0.0019)$ low in the breast cancer group as compared with control. This finding agrees with that reported in previous studies [25]. Other study showed

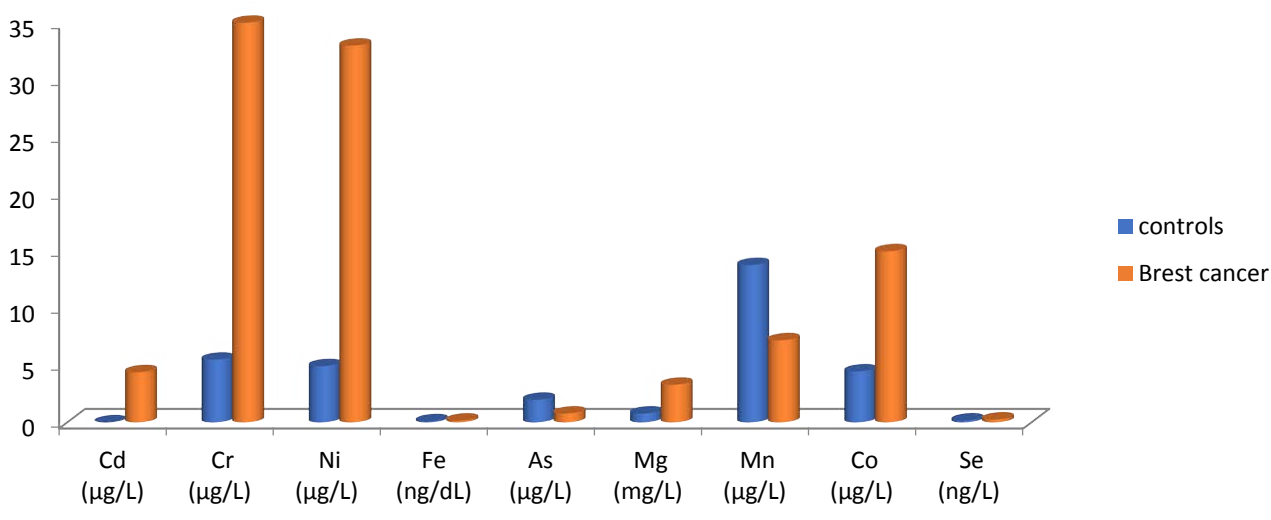

Figure 1: Mean serum trace element levels in breast cancer patients compared with healthy controls. 
Citation: Ismail PAS, Yousif AM, Harki EMT (2017) Alterations of Some Heavy Metals and Trace Elements Levels in Breast Cancer. Med Chem (Los Angeles) 7: 758-760. doi: 10.4172/2161-0444.1000426

low results of Mn levels in the serum of the breast cancer patients. Mn is acts as an antioxidant defense and forms a part of SOD enzyme. When Mn levels reduced, the mechanism of antioxidant disrupted and it sensitized the target organs to the carcinogens [26]. According to the theory, Mn levels influencing the oxidation status which can affect in the oxidant/antioxidant imbalance in breast cancer patients. There is no data available associating $\mathrm{Mn}$ with cancers [27]. But occurrence of thyroid tumors in mice (male and female) and pancreatic tumors in rats (male) were revealed due to massive exposure [28].

The serum As level was significantly $(\mathrm{p}<0.001)$ low in the breast cancer group than in the control as shown in Figure 1. The low levels of As may be due to its consumption by cancerous cells during the growth of the breast cancer. Food such as fish is considered the major source for human exposure to arsenite. In bone tissue arsenic may replace phosphorus and can be saved for years [29]. Stoica et al [30] explaind that the influence of arsenite on estrogen hormone, which regulated genes in the human ER-positive breast cancer cell. Arsenite is more sensitive than estrodiol in binding to ER-alpha, then it elevated cell growth and it imitates the influences of estradiol, which reduced the amount of ER-alpha and raised the expression of the progesterone receptor. Arsenite was able to activate ER-alpha at levels as low as 1 nanomole.

As shown in Figure 1 there was significant $(\mathrm{p}<0.05)$ increase in levels of serum Co in breast-cancer patients compared to healthy controls. The mechanisms of Co carcinogenicity include direct DNA breaks, oxidative DNA breakdown through ROS synthesis, endocrine disrupters, etc. [31].

\section{References}

1. Hunter DJ, Willett WC (1993) Diet, body size, and breast cancer. Epidemio Rev 15: 110-132.

2. Willett WC, Browne ML, Bain C, Lipnick RJ, Stampfer MJ, et al. (1985) Relative weight and risk of breast cancer among pre-menopausal women. Am J Epidemiol 122: 731-740.

3. Jevtic M, Velicki R, Popovic M, Cemerlic-Adjic N, Babovic SS, et al. (2010) Dietary influence on breast cancer. J BUON 15: 455-461.

4. Adebamowo CA, Hu FB, Cho E, Spiegelman D, Holmes MD, et al. (2005) Dietary patterns and the risk of breast cancer. Ann Epidemiol 15: 789-795.

5. Capel ID, Pinnock MH, Williams DC, Hanham IW (1982) The serum levels of some trace and bulk elements in cancer patients. Oncology 39: 38-41.

6. Sandstead HH, Klevay CM (2010) Trace element nutrition and human health. J Nutr 130: 4835-4845.

7. Rodushkin I, Ödman F, Olofsson R, Axelsson MD (2000) Determination of 60 elements in whole blood by sector field inductively coupled plasma mass spectrometry. J Anal At Spectrom 15: 937-944.

8. Zar JH (2001) Biostatistical analysis (4thedn). Prentice Hall, New Jersey.

9. Sadat N, Hossain I, Hossain K, Reza S, Nahar Z, et al. (2008) Serum trace elements and immunoglobulin profile in lung cancer patients. Journal of Applied Research 8: 24-34.

10. Siewit CL, Gengler B, Vegas E, Puckett R, Louie MC (2010) Cadmium promotes breast cancer cell proliferation by potentiating the interaction between ER alpha and C-Jun. Mol Endocrinol 24: 981-992.

11. Martin MB, Reiter R, Pham T, Avellanet YR, Camara J, et al. (2003) Estrogenlike activity of metals in MCF-7 breast cancer cells. Endocrinology 144: 24252436.
12. Hayes RB (1997) The carcinogenicity of metals in humans. Cancer Causes Control 8: 371-385.

13. Coyle YM, Hynan LS, Euhus DM, Minhajuddin AT (2005) An ecological study of the association of environmental chemicals on breast cancer incidence in Texas. Breast Cancer Res Treat 92: 107-114.

14. Feder JN, Gnirke A, Thomas W, Tsuchihashi Z, Ruddy DA, et al. (1996) A nove $\mathrm{MHC}$ class I-like gene is mutated in patients with hereditary haemochromatosis. Nat Genet 13: 399-408.

15. Leonard SS, Bower JJ, Shi X (2004) Metal-induced toxicity, carcinogenesis, mechanisms and cellular responses. Mol Cell Biochem 255: 3-10.

16. Beyersmann D (2002) Effects of carcinogenic metals on gene expression Toxicol Lett 127: 63-68.

17. Kiziler AR, Aydemir B, Onaran I, Alici B, Ozkara H, et al. (2007) High levels of cadmium and lead in seminal fluid and blood of smoking men are associated with high oxidative stress and damage in infertile subjects. Biological trace element research 120: 82-91.

18. Stoica A, Pentecost E, Martin MB (2000) Effects of arsenite on estrogen receptor-alpha expression and activity in MCF-7 breast cáncer cells. Endocrinology 141: 3595-3602.

19. Hamilton AS, Mack TM (2003) Puberty and genetic susceptibility to breast cancer in a case-control study in twins. N Engl J Med 348: 2313-2322.

20. Johnson MD, Kenney N, Stoica A, Hilakivi-Clarke L, Singh B, et al. (2003) Cadmium mimics the in vivo effects of estrogen in the uterus and mammary gland. Nat Med 9: 1081-1084.

21. Könemann S, Bölling T, Matzkies R, Willich N, Kisters K, et al. (2005) Iron andiron-related parameters in oncology. Trace Elem Electrolytes 22: 142-149.

22. Rotruck JT, Pope AL, Ganther HE, Swanson AB, Hafeman DG, et al. (1973) Selenium: Biochemical role as a component of glutathione peroxidase. Science 179: $588-590$.

23. Becker JS, Matusch A, Depboylu C, Dobrowolska J, Zoriy MV (2007) Quantitative imaging of selenium, copper, and zinc in thin sections of biological tissues (slugs-genus Arion) measured by laser ablation inductively coupled plasma massspectrometry. Anal. Chem 79: 6074-6080.

24. Son EW, Lee SR, Choi HS, Koo HJ, Huh JE, et al. (2007) Effects of supplementation with higher levels of manganese and magnesium on immune function. Arch Pharm Res 30: 743-749.

25. Johnson S (2001) The possible crucial role of iron accumulation combined with low tryptophan, zinc and manganese in carcinogenesis. Med Hypotheses 57 539-543.

26. Mazdak H, Yazdekhasti F, Movahedian A, Mirkheshti N, Shafieian M (2010) The comparative study of serumiron, copper, and zinc levels between bladder cáncer patients and a control group. Int Urol Nephrol 42: 89-93.

27. Smith D, Gwiazda R, Bowler R, Roels H, Park R, et al. (2007) Biomarkers of Mn exposure in humans. Am J Ind Med 50: 801-811.

28. Morello M, Zatta P, Zambenedetti P, Martorana A, D'Angelo V, et al. (2007) Manganese intoxication decreases the expression of manganoproteins in the rat basal ganglia: An immunohistochemical study. Brain Res Bull 74: 406-415.

29. Bartolome B, Cordoba S, Nieto S, Fernandez-Herrera J, Garcia-Diez A (2009) Acute arsenic poisoning, clinical and histopathologicfeatures. British Journal of Dermatology 141:1106-1109.

30. Stoica A, Pentecost E, Martin MB (2010) Effects of arsenite on estrogen receptor-alpha expression and activity in MCF-7 breast cancer cells Endocrinology 141: 3595-3602.

31. Yaman M, Kaya G, Simsek M (2010) Comparision of trace elements concentrations in cancerous and non-cancerous human endometrial and ovary tissues. Int J Gynecol Cancer 17: 220-228. 